\title{
3 The emergence of environmental journalism in 1960s Sweden
}

\author{
Methodological reflections on working \\ with digitalised newspapers
}

\section{David Larsson Heidenblad}

Digitalisation is changing the conditions for historical research on postwar Scandinavian knowledge societies. In the last few years, vast amounts of topical source material - such as books, governmental reports, parliamentary minutes, and newspapers - have become digitalised and text-searchable. This new digital infrastructure has shifted the outer bounds of what is possible by enabling us to use new methods for distant reading, such as text mining and topic modelling. ${ }^{1}$ In practice, however, most historians do not employ these new techniques. Yet, digitalisation has profound - if seldom acknowledged - effects on traditional research as well. For example, the traditional practice of collecting source material from microfilmed newspapers no longer requires weeks in the library but a day or so in front of a computer screen. This is a poignant example of what Lara Putnam has referred to as "shifting the center of the easy", ${ }^{2}$ a phenomenon I believe most active historians have experienced first-hand over the last years. Yet, to date, few of us have turned our experiences into writing. ${ }^{3}$ Hence, in this chapter I seek to substantiate, and methodologically reflect upon, the practical implications of working with digitised source materials. I do so by discussing and demonstrating how the recent digitalisation of newspapers has made journalists more visible as knowledge actors. This is a way of answering calls for historians of knowledge to broaden the repertoire of actors involved in societal circulation processes. ${ }^{4}$

Journalists, to be sure, are by no means invisible in Scandinavian historiography of the postwar era. On the contrary, their texts enjoy a somewhat privileged position, as most historical accounts of the period partially draw upon newspaper material. Yet, compared to other public figures of the era - such as politicians, intellectuals, scholars, and scientists - journalists are rarely studied as historical actors in their own right. They are indirectly present in our studies through their texts, but their activities hardly ever receive closer analytical attention. Hence, I would argue that journalists are but semi-visible. To redress this situation, we need to start following them closely in their tracks, which is now practically possible. A few years ago, it was not. The advent of textsearchable digital newspaper archives, such as the Norwegian bokhylla.no and the Swedish newspaper database tidningar.kb.se, serves a necessary prerequisite for this kind of research. 
In this chapter, I demonstrate and discuss this new visibility by highlighting the trajectories of two Swedish journalists: Barbro Soller (1928-2020) and Tom Selander (1923-1978). They are studied in relation to the so-called "ecological turn" - that is, the emergence of modern environmentalism in the late 1960s and early 1970s. ${ }^{5}$ Neither Barbro Soller nor Tom Selander is unfamiliar to environmental historians; however, their turn to environmental journalism in the 1960s has not been studied in depth. ${ }^{6}$ One reason for this is that such a venture, until recently, would have been a very time-consuming prospect - as none of them have a personal archive. Hence, their prospective historian would have had to trawl through years of microfilmed newspapers in order to assemble a sufficient body of source material.

This situation contrasts sharply with more visible actors of the ecological turn, such as diplomat Rolf Edberg (1912-1997) and scientist Hans Palmstierna (1926-1975). Their personal archives, including a vast array of correspondence, are veritable treasure troves for historians. Moreover, both Edberg and Palmstierna used subscription services to receive clippings whenever their names were mentioned in the press. This was a widespread practice up until the 1990s among certain groups of elite actors in Sweden. Through press clippings and correspondence, it is possible to follow them very closely. Hence, the visible elite provides historians with both ample and conveniently accessible source material to draw upon. Consequently, their visibility tends to become even further pronounced by posterity. ${ }^{7}$

The recent digitalisation of newspapers does not in itself change this situation. Archival conditions can but shape, not determine, how historians conduct their research. Moreover, the actual implications of digitalised newspapers on historical research are quite hard to determine based on our publications, as we rarely discuss this "invisible method". ${ }^{8}$ For example, we commonly do not distinguish between how we have accessed newspaper material; that is, whether we have used originals, microfilmed copies, clipping archives, or digital archives. Yet, the various forms we use most certainly have consequences for the text corpuses we find and the way in which we process them. ${ }^{9}$ In the case of digitalised newspapers, the most significant feature is that they are text-searchable. Hence, as Lara Putnam emphasises, words and concepts become more available than ever before. ${ }^{10}$ Consequently, historians are able to get a quick overview of when certain terms came into use or fell out of fashion. This has fuelled a trend towards conceptual history that has been accentuated in, and by, the data-driven field of digital history. ${ }^{11}$ Yet, digitalised newspaper archives contain much more than searchable terms - there are plenty of actors to search for as well, such as the journalists involved in the making of the ecological turn.

\section{Visible journalists and the moulding of archives}

The cases of Barbro Soller and Tom Selander represent a good starting point for discussing the new visibility of journalists, as well as the more general question of the systematic biases of text-searchable archives. These two journalists 
are among the most visible in the digitalised Swedish newspaper archives of the 1960s. The reason for this is twofold. First, the newspapers they wrote for - Dagens Nyheter and Svenska Dagbladet - have survived up until today and have financed the digitalisation of their own archives. Other large and influential Swedish newspapers of the 1960s have not survived, such as StockholmsTidningen and Arbetet. This is important, as Dagens Nyheter and Svenska Dagbladet have made their archives available to their subscribers. Hence, for a fee, they are accessible to anyone anywhere, in contrast to the national database tidningar.kb.se, which is only available at the National Library in Stockholm and from certain computers in university libraries. Second, both Barbro Soller and Tom Selander are rather unusual names. For that reason, when you enter their name into the search engine, you do not get a flood of irrelevant results. Historical actors with common names, say "David Larsson" or "Anna Nilsson", do not fare as well. In fact, Barbro Soller and Tom Selander are actually easier to trace than Hans Palmstierna. This is because the latter had a younger sister Gunilla Palmstierna-Weiss (b. 1928) - who was a vocal activist against the Vietnam War in the 1960s and thus occurred more frequently in the press than her older brother. In addition, the name "Hans" is a common Swedish pronoun, equivalent to "his", which further blurs the search results. To be sure, Hans Palmstierna is still possible to follow - after all, he is no David Larsson or Anna Nilsson - but his case illustrates that the historical context determines what is text-searchable. Moreover, it shows that simplistic quantitative measures are to be used very cautiously, if at all, when we follow historical actors.

The case of Barbro Soller further accentuates the necessity of contextual knowledge. When searching for her name in the digital archive of Dagens Nyheter, there are some scattered hits in 1964 and 1965, just over a dozen in 1966, and a lot more from 1967 onwards. Taken at face value, this result is quite surprising, as the scholarly literature unanimously declares that Barbro Soller started working for Dagens Nyheter in 1964, which she also did. ${ }^{12}$ However, as stated in one of the search results from 1964, during her first years at the newspaper, she mainly wrote under the signature "Barbara". Luckily, the name Barbara was rather uncommon in Sweden at the time, yet the search result for the three-year period 1964-1966 gives more than 1,000 hits, most of which are irrelevant. Hence, as in the case of Hans Palmstierna, the mapping of Barbro Soller's activities requires quite some groundwork. However, it is crucial that some quick searches in the digital archive can convince a researcher that this groundwork is a worthwhile pursuit. Compared to the trawling of microfilm which would have to be rather meticulous in order to find all articles written by the signatures Barbara and Barbro Soller - the digitalised newspaper archives are very practical.

However, the new digital infrastructure does not render older systems obsolete. On the contrary, they can make them even more useful. In my work on Tom Selander, I accessed all the material from the digital archive of Svenska Dagbladet. I did not physically leave my office. Yet, the prerequisite for this was old index cards that were scanned and sent to me by mail by the current 
editor. Through these index cards, I knew exactly which dates Tom Selander wrote essays in the section "Under strecket", in total 73 times, between 1947 and 1977. Simply searching for "Tom Selander" over these years results in 2,195 hits. Hence, the index cards of Svenska Dagbladet were instrumental for making my research feasible.

On a more general level, the practice of indexing Swedish press material was rather thorough in the 1960s. One key resource for historians is Svenska tidningsartiklar, which indexes a large number of articles by topic and name. For example, this index makes finding reviews of books a fairly simple procedure, at least for scholars with access to a university library with microfilmed newspapers. An even more powerful resource is the press clipping archive at the Sigtuna Foundation. This is one of Sweden's largest collections of press clippings from the twentieth century, and it is conveniently structured in boxes sorted by topic and by name. Moreover, two times a year, scholars may apply for scholarships to stay for a week with room and board at the Sigtuna Foundation to work in the archive. This generous infrastructure has formed the basis for many dissertation projects. However, as Johan Jarlbrink has pointed out, the Sigtuna clipping archive is by no means a neutral conveyor of the past. ${ }^{13}$ There are systematic biases and blind spots that researchers are well advised to keep in mind. For example, serious essays by intellectuals on the cultural pages of newspapers are prevalent, whereas more mundane forms of journalism are not. This is mirrored in the indexes of Svenska tidningsartiklar. However, systematic biases are by no means unique to index services. All archives - not least fully text-searchable digitalised newspapers - shape historical research in specific ways, primarily, I would argue, by making certain practices easy and efficient.

In my own research on the ecological turn, I have worked with all the previously mentioned archival forms. To me, this has clarified that what is visible for historians depends a great deal on the archives we work with. In 2014, when I started, there were no digital newspaper archives and I had limited knowledge of the relevant personal archives. Hence, I conducted my first studies by trawling microfilm over periods where I could reasonably expect to find something of interest. This was a tedious method. However, I also learnt a great deal about how much text newspapers of the time actually contained. To me, this was a sobering experience. Later on, when I began working with material from the Sigtuna Foundation and digital newspaper archives, I kept in mind that - after all - this was but a tiny fraction of what newspapers were about. My experiences of searching for needles in a haystack is important, since in the wake of digitalisation, it has become easy to find needles without ever experiencing the haystack. Lara Putnam describes this as the rise of decontextualised reading. ${ }^{14}$ For us as historians, there are many risks involved in these developments, and we need to discuss these more seriously. However, this should not stop us from pursuing some of the new lines of research enabled by the digitalisation of source material. In the following, I demonstrate one such possibility by highlighting the role of journalists as knowledge actors in the ecological turn in Sweden. 


\section{Barbro Soller's early years at Dagens Nyheter, 1964-1966}

Barbro Soller is widely recognised as the first full-time employed environmental journalist in Sweden. This was established by Monika Djerf Pierre in her 1996 dissertation Gröna Nyheter, which has served as a key reference for environmental historians and media scholars alike ever since. The topic of her dissertation, however, is not the Swedish press but environmental journalism in television news, from the early 1960s up to the 1990s. Barbro Soller plays a special role in this audio-visual history as well, as she in 1972 became the first formally employed environmental journalist on Swedish television. In this role, she pioneered a new form of critical investigative journalism. ${ }^{15}$ Yet, Djerf Pierre's rich account touches upon much more than television news. Based on an interview with Barbro Soller conducted in the early 1990s, she establishes that Soller became the first full-time employed environmental journalist at Dagens Nyheter in 1964. ${ }^{16}$ Djerf Pierre did not have any reasons not to trust Soller on this account; however, memories are fragile and three decades is a long time. What happens if we go to the digital newspaper archive and search for Barbara in 1964?

The search results in 317 hits, many of which are irrelevant, as there were quite a few international luminaries named Barbara at the time. However, we also find many articles written by Barbro Soller, and we get visual and textual evidence that she was part of the "DN team" of 182 journalists. ${ }^{17}$ To the readership, Soller is presented as a general reporter, which, indeed, she seems to have been. In 1964, she wrote about classical music, art exhibitions, celebrities visiting Stockholm, wildlife, and a multitude of other topics. She reported about the boxer Floyd Patterson, Charlie Chaplin's visit to the Vasa Museum, as well as the ambition of a local choir to travel to America ${ }^{18}$ Hence, it is a stretch to say that she was a full-time employed environmental journalist in 1964.

However, there are merits to Barbro Soller's memories. In the spring of 1964, she indeed wrote a number of featured articles on mercury-poisoned eggshells. These instalments ran in February and March 1964 and made the frontpage of Dagens $N$ heter (which few of her other articles did at the time). In these pieces, she reported on new research findings and conducted interviews with leading scientists. ${ }^{19}$ Moreover, she also wrote about the activities of young field biologists, biological school excursions, and a national conference on the problem of noise. ${ }^{20}$ In sum, in 1964 Barbro Soller was a general reporter at Dagens Nyheter, who took a special interest in environmental problems, wildlife, and biology. However, she seems to have been just as interested in classical music and wrote regularly on visiting celebrities.

This particular phase of Barbro Soller's career stretches from 1964 to 1966. Up until then, her topical focus varied and included articles on youth gospel choirs, the working day of a professor, and lifeguards in Swedish seaside resorts. ${ }^{21}$ One distinctive feature of her journalism was longer essays on animals. These kind of texts were frequently complemented with rich colour photographs and published in Sunday supplements. I would describe them as 
a form of apolitical nature journalism. ${ }^{22}$ In October 1967, Soller even got her own Q\&A section in the newspaper named "Ask about animals" ("Fråga om djuren"). ${ }^{23}$

However, Barbro Soller's position in Dagens Nyheter grew stronger and in the spring of 1966, she did her first high-profile feature series, the topic being the looming hunger crisis in India. Dagens Nyheter advertised the series in advance, and all three instalments dominated the frontpage of their respective issue. ${ }^{24}$ The series was a collaboration between Soller and photographer Stig A. Nilsson (1930-2003), who travelled together with her in India for a month. Interestingly, the publication coincides with a change of signature - from Barbara to Barbro Soller-Svensson. Still, this shift was gradual, and throughout the mid1960s, she altered between her three different signatures.

Barbro Soller's journalistic role in the India series was that of the engaged reporter. Here, she was part of a larger trend, towards a form of journalism that was more personal and activist in nature. Media scholars describe this in terms of a change in journalistic ideals during the 1960s, from objective reflection to critical investigation. ${ }^{25}$ This shift was intertwined with a larger process of professionalisation for journalists in Scandinavia, marked by a weakening of the ties between the press and the political parties. ${ }^{26}$ An integral part of this development was new formalised journalism programmes, which were launched in Sweden in 1962 and in Norway in 1965. ${ }^{27}$ These changes enabled many journalists to take on a more autonomous role. For Barbro Soller, this coincided with the ecological turn.

\section{Barbro Soller and the ecological turn}

The fall of 1967 was a formative moment in Swedish environmental history. During this period, the environmental debate took off. An absolutely crucial factor was that a number of well-respected Swedish scientists raised the alarm concerning an ongoing environmental crisis. Public attention was drawn to the notion that proverbial environmental hazards, such as biocides, mercury poisoning, and sulphur emissions, did not constitute isolated problems. Rather, they were part of a complex and interrelated web of environmental degradation, which constituted a serious threat to the survival of man. ${ }^{28}$ Leading actors, such as Rolf Edberg and Hans Palmstierna, linked various environmental issues to other global concerns, notably the looming threat of overpopulation, which Soller had discussed in her India series the year before. ${ }^{29}$

Barbro Soller's own transition from being a general reporter to becoming an environmental journalist seems to have taken place during the fall of 1966. By early 1967, she wrote exclusively about environmental issues and the natural world. Her primary signature was still Barbara, but her role had changed. In the yearly presentation of the "DN team", she was introduced as one of the foreign correspondents. ${ }^{30}$ However, judging by what she actually wrote, I would say that she had now indeed become Sweden's first full-time employed environmental journalist. As such, she was instrumental for the societal circulation 
of environmental knowledge. She served as a link between the public at large and the concerned scientists, who in the mid-1960s rarely directly entered the public fray. ${ }^{31}$ During the first half of 1967, Barbro Soller wrote extensively about mercury in fish, warned of the poisoning of Lake Mälaren, discussed the implications of delayed political investigations of oil damage, and interviewed Rolf Edberg. ${ }^{32}$ In addition, she continued to write apolitical nature journalism about wildlife and new ethological research findings. ${ }^{33}$

Barbro Soller's journalistic activity intensified in the fall of 1967 , and it was during these eventful months that she finally adopted "Barbro Soller" as her main signature. An important topic at the time was the discovery of dangerous levels of mercury in Swedish freshwater fish, which resulted in a ban on selling fish caught in about 40 Swedish lakes. ${ }^{34}$ In addition, Svante Oden's alarm of acid rain demonstrated the international dimensions of environmental pollution. ${ }^{35}$ For Soller, the heated debate resulted in more contacts with scientists, politicians, and governmental agencies. ${ }^{36}$ However, she did not engage in investigative environmental journalism in 1967 , but that was about to change.

\section{Barbro Soller's "New Filth-Sweden"}

Barbro Soller's public breakthrough as an environmental journalist was the ambitious series of articles titled, "Lort-Sverige 30 år senare" ("Filth-Sweden 30 Years Later") in 1968. It ran in Dagens Nyheter from March to June and covered a number of environmental issues. The title of the series paraphrased Ludvig Nordström's (1882-1942) well-known social report book Lort-Sverige (1938), which had exposed the harsh and filthy living conditions of the poor in the 1930s. ${ }^{37}$ Nordström's book had a profound impact on the formation of social democratic policy and the expansion of the modern welfare state. Soller's main argument was that the sanitary problems had not disappeared; they had just been relocated. Swedish homes were cleaner in 1968 than in 1938 - but as a result, Swedish nature had become polluted. For the air, soil, water, and wild animals, the consequences of rising affluence were dire.

The feature series was yet another collaboration between Barbro Soller and photographer Stig A. Nilsson. They travelled through Sweden together in the spring of 1968, just as they had travelled through India two years earlier. Soller's texts and Nilsson's pictures exposed polluting activities and environmental decay. All seven instalments were frontpage material, at times with colour photographs. Every piece began by Soller alluding to Ludvig Nordström, thereafter linking his description of Sweden in the 1930s to subsequent developments. In the series, Soller had a special focus on the environmental consequences of modern conveniences, such as cars, water closets, washing machines, and dishwashers. For example, she portrayed a modern "villa family" in Värmland and got the State Institute for Building Research to measure the environmental impact of their affluent lifestyle. On the frontpage, the young couple stood in front of their new house, holding their two kids. The caption read "Modern machines make life comfortable. But at what cost?" 38 
"Lort-Sverige 30 år senare" also included reports on agriculture and industry. Soller contrasted the problems of lice and flies in the 1930s with the widespread use of pesticides in the 1960s. In 1968, the environmental debate on biocides was well-established, but Soller wanted to report on how the farmers themselves experienced this new situation. The frontpage displayed a colour photograph of a man in protective clothing and a mask standing in front of a cart full of chemicals. In the text, Soller told the story of how this man - the director of a machine station - was responsible for the weed control of about 6,000 hectares. It demonstrated that agriculture had become an industry-scale phenomenon with major environmental consequences. ${ }^{39}$

The last instalment of the series focused on the paper and pulp industry in the city of Sundsvall. Soller examined the activities of Svensk Cellulosa (SCA), one of Sweden's largest corporations at the time. She told the story of how Ludvig Nordström was impressed by the factory smokestacks when he arrived in Sundsvall. To him, it was a symbol of industrial progress. To Soller, it was a massively polluting industry. She discussed how SCA used the ocean as a dumpster, not taking into consideration the long-term consequences of the disposal of chemicals. ${ }^{40}$ The following day, the entire series was lauded in the editorial section of Dagens Nyheter. The piece emphasised the need for a discussion on how the costs for environmental restoration and preventive measures should be distributed in society. There was an emerging environmental consciousness in Sweden, but it had to be followed by a new willingness to take economic responsibility. Politicians, large corporations, agricultural sectors, scientists, and the people had to work together to redress the situation. ${ }^{41}$

In 1968, Barbro Soller's article series reached the large number of readers of Dagens Nyheter. In 1969, it reached a new audience, as Rabén \& Sjögren (the same publishing house that Hans Palmstierna worked with) published the series in a revised form as the paperback Nya Lort-Sverige ("New Filth-Sweden"). The book was richly illustrated by Stig A. Nilsson's black-and-white photographs, which served as visual evidence of Soller's arguments. The cover featured a spring scenery from a forest, where coltsfoot rose through litter. Inside, Soller started off by portraying Stockholm as a city for cars, unfit for pedestrians. Particularly illustrious was a photograph of a man holding up a white filter that had turned black in an hour of morning traffic. ${ }^{42}$

Nya Lort-Sverige received positive reviews and was printed in a second edition in 1970. However, compared to the major environmental bestsellers of the era, such as Hans Palmstierna's Plundring, Svält, Förgiftning (1967) and Gösta Ehrensvärd's Före-Efter (1971), Soller's book was not a huge commercial success. However, the article series established her as an environmental journalist with an independent critical agenda. In the spring of 1969, she and photographer Stig A. Nilsson produced a new ambitious feature series for Dagens Nyheter, where they sought to uncover the inner workings of the Swedish meat industry. The series "Djurfabriken" ("The Animal Factory") ran from March to June but was not promoted as heavily as "Nya Lort-Sverige". For example, only the first instalment appeared on the frontpage. This feature series marked 
the end of Barbro Soller's years at Dagens Nyheter. However, it was but the beginning of her long career as an environmental journalist. ${ }^{43}$ In the following, I examine another journalist who changed course in the 1960s.

\section{Tom Selander and the future of humanity}

Unlike Barbro Soller, Tom Selander is no longer a household name for environmental historians. However, in the late 1960 s and early 1970 s, he was instrumental in the Swedish public debate on the future of humanity. In my own research on the ecological turn, he is frequently present through reviews, essays, and article series. However, I had not been able to find much information about him through online searches or biographical lexica. Yet, when asked in 2018 to contribute to the centennial jubilee of the daily essay section in Svenska Dagbladet, "Under strecket", I decided to use this opportunity - and the newly digitalised newspaper archive - to follow Tom Selander. The index cards provided by the editor guided my gathering of source material. This combination of old and new search engines made it possible to find, and read, 73 essays written by Tom Selander from 1947 to 1977 . It was a practical method for following a journalist's intellectual development over three decades. ${ }^{44}$

What I knew of Tom Selander, apart from his interest in future studies around 1970, was that he was the son of poet, author, and botanist Sten Selander (1891-1957). The father was a well-known and versatile public intellectual, who was on the Swedish Academy and was the president of the Swedish Society for Nature Conservation. Environmental historians have portrayed him as a precursor to modern environmentalism in Sweden. ${ }^{45}$ In the 1940 s and 1950s, Sten Selander regularly wrote for Svenska Dagbladet, not least "Under strecket". Hence, between 1947 and 1957, the readership met two generations of Selander. Sten wrote about literature and nature, while Tom explored the political landscape of continental Europe. ${ }^{46}$ Tom took a special interest in youth, school issues, and the world awaiting his own generation. ${ }^{47}$ In 1954, Tom got a permanent position at Svenska Dagbladet as a foreign correspondent in Bonn. Throughout the 1950s, he reported about current European events, often in the form of travelogues.

However, in the early 1960s, Tom's essays took a new direction. It began with an enthusiastic review of a local historical account of the island of Möja in the Stockholm archipelago. The book portrayed the coming of modernity at the turn of the century, and Tom reflected upon the vast cultural rift separating him and his contemporaries from the world that had vanished so recently. ${ }^{48}$ In the wake of this essay, Selander started writing about sailing, especially adventurous sailing. He wrote vividly about Joshua Slocum (1844-1909), the first man to sail around the world by himself. ${ }^{49}$ Tom Selander's essays from the early and mid-1960s contain a mild form of civilisation criticism, which resembled his father's stance in Det levande landskapet $i$ Sverige (1955). During these years, Tom turned his back on the political world, which had captivated him in the past. 
In 1967, however, Tom's journalism took yet another turn. The reason being that he travelled to India, just as Barbro Soller had done in 1966. In a fourseries instalment, he reported on extreme poverty, overpopulation, and the massive political challenges ahead. ${ }^{50}$ Thereafter, Tom Selander no longer wrote about sailing. He took an intense interest in global concerns and the future of humanity. Initially, his essays centred on foreign aid and the need for economic development; however, his newfound interest led him to engage in the emerging field of future studies. ${ }^{51} \mathrm{He}$ interviewed 24 Swedish so-called "future experts", including Hans Palmstierna, and published his findings in the article series "Sverige år 2000" ("Sweden in the Year 2000"), which ran from December 1968 to March 1969. Two months later, Rabén \& Sjögren published the series as a paperback. ${ }^{52}$

Tom Selander's interest in future studies characterised his essays in the 1970s. He was an avid reader and introduced a wealth of international literature and debates to a Swedish audience. ${ }^{53} \mathrm{He}$ travelled as a reporter to the United States to witness first-hand how future research was carried out. In the spring of 1972, he produced a new ambitious interview series "Överleva, men hur?" ("Survive, but How?"), which intervened in the heated Swedish debate on Gösta Ehrensvärd's Före-Efter: En diagnos (1971). ${ }^{54}$ Until his death in 1978, Tom Selander served as a link between international scientists, global developments, and the readers of Svenska Dagbladet.

The daily essay section "Under strecket" has been characterised by Johan Östling as a special form of "knowledge arena". In the 1960s and 1970s, it linked certain intellectuals, scholars, and scientists to a wider readership. ${ }^{55}$ Svenska Dagbladet was a conservative newspaper that differed from the liberal Dagens Nyheter, which undertook a distinct turn to the left over the course of the 1960s. ${ }^{56}$ Hence, for young people in the 1960 s and 1970 s getting engaged in new social movements - such as the environmental movement - Tom Selander was not a household name. He was not visible to them, even though he wrote extensively on the Club of Rome, Barry Commoner (1917-2012), and the attempts to replace GDP with QOF (Quality of Life). ${ }^{57}$ However, in the digitalised newspaper archives of the 2010s, his role in the ecological turn is more visible than ever.

\section{The digitised turn}

The impetus for this chapter has been Lara Putnam's seminal article "The Transnational and the Text-Searchable: Digitized Sources and the Shadows they cast", which was published in American Historical Review in 2016. Putnam argues that digitalisation has caused a discipline-wide transformation, as historical scholarship at heart is about "finding and finding out". ${ }^{58}$ Google, Google Books, JSTOR, and various forms of library databases - such as Libris in Sweden - now profoundly shape these activities. In a discipline-wide perspective, the development of new digital methods is rather marginal. "Shifting the outer bonds of the possible", Putnam claims, "matters less than shifting the center of 
the easy.' Hence, the perhaps most important change for the historical profession in the twenty-first century is that OCR technology has made full textsearchability the norm. ${ }^{59}$

In this chapter, I have demonstrated that certain journalists are now easy to follow. We can map their careers and writings, without ever leaving our offices. Hence, the digitalisation of topical source materials frees us from certain spatial constraints. While practical and efficient, there are many risks involved. Putnam warns of decontextualised reading, especially in relation to source material from historical contexts about which we know very little. Previously, such material was only accessible by travelling to distant libraries and archives. During these travels, historians have been prone to interact with others - scholars, librarians, and archivists - who knew a great deal more than the historian about the specific context. Today, search engines generally circumvent these actors, to the detriment of historical scholarship. ${ }^{60}$

Moreover, Putnam points out that digitalisation and the transnational turn are parallel processes. She argues that this is not a mere coincidence. Rather, she stresses that the ideal of transnational history gained strength in tandem with the digital infrastructure, which made it easier to conduct transnational history. Putnam highlights "side-glancing": that is, a quick search to determine what is going on in your topical area in another scholarly community. ${ }^{61}$ Traditionally, the strongest communities have been organised nationally, and in my experience, they still are - even though the critics of this paradigm are vocal, not least in Scandinavia. ${ }^{62}$

Still, there are certain strengths in the traditional organisation of historical scholarship. One is that there is a large amount of shared contextual knowledge: of past events and processes, of historical actors and networks, of source materials, and of archives and archival practices. This type of knowledge is not, at least in my experience, typically present in international research networks. Hence, for empirically oriented historians, the national paradigm - with all its problems and pitfalls - is still very valuable in practice.

However, these types of scholarly communities are not a given. They can evolve, prosper, decay, and transform. The new digital infrastructure opens up many new possibilities for us to conduct empirical transnational research. This should be embraced. However, if the digital infrastructure is not intertwined with a social infrastructure - where historians from various communities and contexts discuss, help, criticise, and collaborate with each other - decontextualised readings are prone to prosper. This will not do our profession any good.

Moreover, the new digital infrastructures are not quite as accessible as historians would like them to be. For example, the Norwegian bokhylla.no - a terrific service - is not available to me in Lund. I need to be at a Norwegian library. Today, such national constraints are the norm; still, free international access would hardly spur a surge among Swedish historians to study the Norwegian past. Most of us do not have the contextual knowledge necessary nor do we have colleagues in the corridor to ask for directions. Hence, one could argue 
that the centre of the easy is still the university library, the research seminar, the teachers who educate us, and the local contexts we inhabit.

\section{Notes}

This work was supported by the Ridderstad Foundation.

1 Andreas Fickers, "Towards a New Digital Historicism? Doing History in the Age of Abundance", Journal of European Television History and Culture 1, no. 1 (2012); Franco Moretti, Distant Reading (London: Verso, 2013); Kenneth Nyberg and Jessica Parlandvon Essen, Historia $i$ en digital värld (2014), https://digihist.se/ [blog]; Anna Nilsson Hammar, "Digital History", Scandia 81, no. 2 (2015); Andrew Piper, "There Will Be Numbers", Journal of Cultural Analytics, 23 May 2016.

2 Lara Putnam, "The Transnational and the Text-Searchable: Digitized Sources and the Shadows They Cast", American Historical Review 121, no. 2 (2016): 379.

3 Fredrik Norén, "Information som lösning, information som problem. En digital läsning av tusentals statliga utredningar", Nordicom Information 38, no. 3 (2016); Johan Jarlbrink, "Digitala metoder", Nordicom Information 38, no. 3 (2016); Johan Jarlbrink, "Telegrafen på distans: ett digitalt metodexperiment", Scandia 84, no. 1 (2018).

4 Simone Lässig, "The History of Knowledge and the Expansion of the Historical Research Agenda", Bulletin of the German Historical Institute 59 (2016); Johan Östling, David Larsson Heidenblad, Erling Sandmo, Anna Nilsson Hammar, and Kari H. Nordberg, "The History of Knowledge and the Circulation of Knowledge", in Circulation of Knowledge: Explorations in the History of Knowledge, eds. J. Östling, E. Sandmo, D. Larsson Heidenblad, A. Nilsson Hammar, and K.H. Nordberg (Lund: Nordic Academic Press, 2018); Marin Mulsow, "History of Knowledge", in Debating New Approaches to History, eds. Marek Tamm and Peter Burke (London: Bloomsbury, 2019).

5 Jens Ivo Engels, "Modern Environmentalism", in The Turning Points of Environmental History, ed. Frank Uekötter (Pittsburgh: University of Pittsburgh Press, 2010); Joachim Radkau, The Age of Ecology: A Global History (Cambridge: Polity Press, 2014).

6 Monika Djerf Pierre, "The Greening of the News: The Institutionalization of 'the Environment' in Television News Reporting 1961-1973", in A History of Swedish Broadcasting: Communicative Ethos, Genres and Institutional Change, eds. Monika Djerf Pierre and Mats Ekström (Göteborg: Nordicom, 2013).

7 Anke te Heesen, The Newspaper Clipping: A Modern Paper Object (Manchester: Manchester University Press, 2014); David Larsson Heidenblad, "Ett ekologiskt genombrott? Rolf Edbergs bok och det globala krismedvetandet i Skandinavien 1966", Historisk tidsskrift 95, no. 2 (2016); David Larsson Heidenblad, "Överlevnadsdebattörerna: Hans Palmstierna, Karl-Erik Fichtelius och miljöfrågornas genombrott i 1960-talets Sverige", in Efterkrigstidens samhällskontakter, eds. Fredrik Norén and Emil Stjernholm (Lund: Mediehistoriskt arkiv, 2019).

8 Putnam, "The Transnational and the Text-Searchable", 338.

9 Fredrik Norén and Pelle Snickars, "Distant Reading the History of Swedish Film Politics in 4500 SOU Reports", Journal of Scandinavian Cinema 7, no. 2 (2017).

10 Putnam, "The Transnational and the Text-Searchable", 400.

11 Moretti, Distant Reading; Arianna Betti and Hein van den Berg, "Modelling the History of Ideas", British Journal for the History of Philosophy 22, no. 4 (2014); Piper, "There Will Be Numbers".

12 Monika Djerf Pierre, Gröna Nyheter. Miljöjournalistiken i televisionens nyhetssändningar 1961-1994 (Gothenburg: Göteborgsstudier i journalistik och masskommunikation, 1996), 114.

13 Johan Jarlbrink, "Historien i tidningsklipp - tidningsklipp i historien: Klipp i arkiv, dagbok och bokfilm", Historisk tidskrift 130, no. 2 (2010). 
14 Putnam, "The Transnational and the Text-Searchable”, 392-397.

15 Djerf Pierre, Gröna nyheter, 215-222.

16 Ibid., 114.

17 “Ett väl sammansvetsat DN-lag", Dagens Nyheter (hereafter DN), 5 January 1964.

18 Barbara, "De tränar för konsertresa till Amerika", DN, 18 February 1964; Barbara, “Tusen såg vårvernissage i DN-regi", DN, 9 May 1964; Barbara, "Att plocka den är ett brott", DN, 17 May 1964; Barbara, "Ungdom om Chrustjevs besök", DN, 25 June 1964; Barbara, "Sveriges nationalfågel - utsökt kompositör", DN, 27 June 1964; Barbara, "Mera slagsmål med Floyd", DN, 2 July 1964; Barbara, "Svensk renässans för klassisk gitarr", DN, 21 September 1964; Barbara, "Kärlek vid första ögonkastet när Chaplin mötte "Vasa", DN, 3 November 1964; Barbara, "Framtida möte i skogen", DN, 8 November 1964; Barbara, "Hornen avgör renens rang”, DN, 30 December 1964.

19 Barbara, "Kvicksilver i svenska ägg", DN, 22 February 1964; Barbara, "Giftkontroll i stor skala”, DN, 28 February 1964; Barbara, "Sänkt kvicksilverdos aktuell i vårbruket”, DN, 29 February 1964; Barbara, "Våren tystnar", DN, 1 March 1964; Barbara, "Giftet samlas i äggvitan: Skalet tar ingen skada", DN, 9 March 1964; Barbara, "Värpning utanför redet kan förklara fågeldöd", $D N, 11$ March 1964.

20 Barbara, "Eldprov svårast på naturstig", DN, 3 January 1964; Barbara, "Fritt plugg på egen 'skolgård", DN, 29 April 1964; Barbara, "Alla störda av stadens larm: Buller hela dan”, DN, 26 May 1964.

21 Barbara, "Det svänger i kyrkan”, DN, 27 January 1965; Barbara, "En professors vardag", DN, 9 January 1966; Barbara, “Åtta livräddare vaktar Tylösand”, DN, 1 July 1966.

22 Barbara, "Älgar skyr moderlös kalv”, DN, 31 March 1965; Barbara, "Orrtuppen kuttrar året om”, DN, 18 April 1965; Barbara, "Humlan efterlyst i hela världen", DN, 18 June 1965; Barbara, "Lejonslum och tigerlek i djurpark”, DN, 28 October 1965; Barbro Soller, "Bild av universum medfödd hos fågel", DN, 2 October 1966; Barbro Soller, “Det perfekta brottet - i fågelvärlden”, DN, 20 November 1966; Barbara, "Tranforskare sprängde järnridån”, DN, 15 April 1967; Barbro Soller, "Fåglar ni möter i skärgården”, DN, 11 June 1967.

23 Barbro Soller, "Fråga om djuren”, DN, 28 Ocober 1967.

24 Barbro Soller-Svensson, "Hungersnöd hotar 46 miljoner indier: Barn bygger 'Svältens väg'”, DN, 10 May 1966; Barbro Soller-Svensson, "Vattvällingen blandas med torkade blommor", DN, 12 May 1966; Barbro Soller-Svensson, "DN-intervju med Indira Ghandi: 'Indiens värsta år'”, DN, 15 May 1966.

25 Monika Djerf Pierre and Lennart Weibull, Spegla, granska, tolka: Aktualitetsjournalistik $i$ svensk radio och TV under 1900-talet (Stockholm: Prisma, 2001).

26 Stig Hadenius and Lennart Weibull, Partipressens död? (Stockholm: Svensk informations mediecenter, 1991); Daniel Hallin and Paolo Mancini, Comparing Media Systems (Cambridge: Cambridge University Press, 2004); Henrik Bastiansen, Lojaliteten som brast: Partipressen i Norge fra senit til fall 1945-2000 (Oslo: Norsk pressehistorisk forening, 2009); Lennart Weibull, “Är partipressen död eller levande? Reflexioner från ett presshistoriskt seminarium”, Nordicom-Information 35 (2013); Jostein Gripsrud, Allmenningen: Historien om norsk offentlighet (Oslo: Universitetsforlaget, 2017), 406-409.

27 Elin Gardeström, Att fostra journalister: Journalistutbildningens former i Sverige 1944-1970 (Gothenburg: Daidalos, 2011), 185; Gripsrud, Allmenningen, 407.

28 David Larsson Heidenblad, "Mapping a New History of the Ecological Turn: The Circulation of Environmental Knowledge in Sweden 1967", Environment and History 24, no. 2 (2018): 266.

29 Rolf Edberg, Spillran av ett moln. Anteckningar i färdaboken (Stockholm: Norstedts, 1966); Hans Palmstierna, Plundring, svält, förgiftning (Stockholm: Rabén \& Sjögren, 1967). For discussions on the linkages between the population issue and modern environmentalism, see Björn-Ola Linnér, The World Household: Georg Borgström and the Postwar Population-Resource Crisis (Linköping: Linköping University, 1998); Matthew Connelly, Fatal 
Misconception: The Struggle to Control World Population (Cambridge: Belknap Press, 2008); Thomas Robertson, The Malthusian Moment: Global Population Growth and the Birth of American Environmentalism (New Brunswick: Rutgers University Press, 2012).

30 "Ett väl sammansvetsat DN-lag", DN, 12 January 1967.

31 Larsson Heidenblad, "Överlevnadsdebattörerna".

32 Barbara, "Låg fiskkonsumtion i Sverige: Håret berättar om kvicksilver”, DN, 21 January 1967; Barbara, "Giftsamling i vattenintag: Oorganiskt kvicksilver gav utslag i fisklever”, DN, 16 February 1967; Barbara, "Kvinnor har högre halter än männen”, DN, 4 March 1967; Barbro Soller, "Vi plundrar våra barns jord”, DN, 9 April 1967; Barbara, "Ingen vill betala oljeskador", DN, 17 May 1967; Barbara, "Båtkyrkogård vid årstabron”, DN, 30 June 1967; Barbara, "Mälaren om trettio år kan bli oas eller kloak”, DN, 24 August 1967.

33 Barbro Soller, “Djurens sociala problem ämne för 300 forskare”, DN, 26 August 1967; Barbro Soller, “Tidigt hörselskadad fågel lär sig aldrig normal sång”, DN, 15 September 1967; Barbro Soller, "Nya rön om sjakalen: Lever stilla familjeliv", DN, 20 September 1967.

34 Barbro Soller,"Yrkesgrupp hotas av ruin", DN, 13 October 1967; Barbro Soller, "Kvicksilvret i svensk fisk kartlagt", DN, 18 October 1967; Barbro Soller, "Regnet blir allt giftigare: Västsveriges fisk dör ut", DN, 24 October 1967; Barbro Soller, "Fisk i 40-tal vatten otjänlig människoföda trots höjd giftgräns", DN, 15 November 1967.

35 Lars J. Lundgren, Acid Rain on the Agenda: A Picture of a Chain of Events in Sweden 1966-1968 (Lund: Lund University Press, 1998).

36 Barbro Soller, "Miljövården får forskningsråd: Samordning av resurserna", DN, 2 November 1967; Barbro Soller, "Kvicksilverexpert slår alarm: Förgiftad fisk kan ge allvarliga fosterskador", DN, 26 November 1967; Barbro Soller, "Möte om föroreningar", DN, 6 December 1967; Barbro Soller, “Svavelregn påverkar skelettbildningen”, DN, 7 December 1967; Barbro Soller, "Kvicksilverutsläppet vållar miljonförluster”, DN, 9 December 1967.

37 Ludvig Nordström, Lort-Sverige (Stockholm: Kooperativa förbundets bokförlag, 1938).

38 Barbro Soller, “Moderna villan farlig smutshärd: Bekvämlighet hotar miljön”, DN, 11 April 1968.

39 Barbro Soller, "Bondens tysta motstånd: Obetat utsäde går lika bra”, DN, 6 May 1968.

40 Barbro Soller, "Ett 'Lort-hav' vid Sundsvall”, DN, 19 June 1968.

41 Anonymous, "Lort och pengar", DN, 20 June 1968.

42 Barbro Soller, Nya Lort-Sverige (Stockholm: Rabén \& Sjögren, 1969), 15.

43 Djerf Pierre, Gröna nyheter, 215-222.

44 David Larsson Heidenblad, "En framtidsman i det historiska arkivet", Svenska Dagbladet (hereafter $S v D$ ), 5 October 2018.

45 Martin Kylhammar, Den okände Sten Selander: En borgerlig intellektuell (Stockholm: Akademeja, 1990).

46 Sten Selander, "Historia vid landsvägskanten", SvD, 3 July 1955; Sten Selander, "Den dödsdömda ljungheden", SvD, 3 September 1955; Tom Selander, "Expansionen i Västtyskland", SvD, 14 February 1953; Tom Selander, "Sovjetmaktens gränser", SvD, 9 October 1955; Tom Selander, "Tullmurarna vacklar", SvD, 1 February 1957.

47 Tom Selander, "Västeuropas ungdom", SvD, 18 October 1947; Tom Selander, "Morgondagens män”, SvD, 13 October 1951; Tom Selander, “Amerikanska tonåringar", SvD, 10 May 1952; Tom Selander, "Kommunismen i klassrummet”, SvD, 11 September 1954.

48 Tom Selander, "Möja vid sekelskiftet", SvD, 13 November 1961.

49 Tom Selander, "Kapten Slocums märkliga seglats", SvD, 5 January 1963; Tom Selander, "Ensamseglare", SvD, 21 March 1965; Tom Selander,"Storseglare", SvD, 30 January 1967.

50 Tom Selander, "De stryktåligas land", SvD, 10 August 1967; Tom Selander, "Kongresspartiets kris", SvD, 17 August 1967; Tom Selander, "Efter Nehrus drömvärld”, SvD, 23 August 1967; Tom Selander,"Det indiska mardrömsperspektivet”, SvD, 29 August 1967.

51 Jenny Andersson, The Future of the World: Futurology, Futurists, and the Struggle for the Post Cold War Imagination (New York: Oxford University Press, 2018). 
52 Tom Selander, Sverige år 2000: 24 svenska framtidsforskare om morgondagens samhälle (Stockholm: Rabén \& Sjögren, 1969).

53 Tom Selander, "En studie i massförvirring", SvD, 5 December 1970; Tom Selander, "Operation jämvikt", SvD, 2 May 1971; Tom Selander, "Domedagen som bestseller", SvD, 23 March 1972; Tom Selander, "Demokratin utan framtidschans", SvD, 6 April 1975; Tom Selander,"Gycklare vid avgrundsklyftan”, SvD, 28 August 1977.

54 David Larsson Heidenblad, "Framtidskunskap i cirkulation: Gösta Ehrensvärds diagnos och den svenska framtidsdebatten 1971-1972", Historisk tidskrift 135, no. 4 (2015).

55 Johan Östling, "En kunskapsarena och dess aktörer: Under strecket och kunskapscirkulation i 1960-talets offentlighet", Historisk tidskrift 140, no. 1 (2020).

56 Anders Frenander, Debattens vågor: Om politisk-ideologiska frågor i efterkrigstidens svenska kulturdebatt (Gothenburg: Humanistiska fakulteten, 1998); Johan Stenfeldt, Dystopiernas seger: Totalitarism som orienteringspunkt $i$ efterkrigstidens svenska idédebatt (Höör: Agering, 2013).

57 Tom Selander, "Livskvaliteten nytt slagord i USA", SvD, 4 May 1971; Tom Selander, "Priset för överlevnad”, SvD, 27 March 1972; Tom Selander, “Tillväxtens gränser”, SvD, 8 April 1972; Tom Selander, "Romklubbens recept för överlevnad”, $S v D, 14$ November 1974.

58 Putnam, "The Transnational and the Text-Searchable", 378.

59 Ibid., 379.

60 Ibid., 392-397.

61 Ibid., 380-381.

62 See, for example, Bo Stråth, Dorthe Gert Simonsen, Thomas Lindkvist, Anette Warring, and Nils-Erik Villstrand, Evaluering av norsk historiefaglig forskning. Bortenfor nasjonen $i$ tid og rom: Fortidens makt og fremtidens muligheter i nork historieforskning (Oslo: Norges forskningsråd, 2008); Stefan Eklöf Amirell, "Den världshistoriska vändningen”, Historisk tidskrift 128, no. 4 (2008). 